\title{
Gambaran foto toraks pad efusi pleura di Bagian/SMF Radiologi FK Unsrat RSUP Prof. Dr. R. D. Kandou Manado periode November 2014 - Oktober 2015
}

\author{
${ }^{1}$ Melinda G. Lantu \\ ${ }^{2}$ Elvie Loho \\ ${ }^{2}$ Ramli Hadji Ali
}

\author{
${ }^{1}$ Kandidat Skripsi Fakultas Kedokteran Universitas Sam Ratulangi Manado \\ ${ }^{2}$ Bagian Radiologi Fakultas Kedokteran Universitas Sam Ratulangi Manado \\ Email: gabrilamlantu12205@yahoo.com
}

\begin{abstract}
Pleural effusion is defined as excessive accumulation of fluid in the pleural cavity. This condition occurs worldwide and becomes a major problem in developing country including Indonesia. This was a retrospective descriptive study. Samples were the whole data of chest X-ray patients available in the medical record with a radiological diagnosis of pleural effusion. The results showed that there were 77 samples aged $45-59$ years old. Males (65\%) were more frequent than females (35\%). Based on the location of effusion, 31 patients with right pleural effusion, 25 patients with left pleural effusion, and 21 patients with bilateral pleural effusion. Conclusion: Pleural effusion was mostly found among people aged above 20 years old. Chest X-ray was an important investigation t confirm the diagnosis of pleural effusion.
\end{abstract}

Keywords: pleural effusion, chest x-ray

\begin{abstract}
Abstrak: Efusi pleura didefinisikan sebagai penimbunan cairan berlebihan dalam rongga pleura. Penyakit ini terdapat diseluruh dunia, bahkan menjadi problema utama di negaranegara yang sedang berkembang termasuk Indonesia. Jenis penelitian ini retrospekif deskriptif. Sampel penelitian ialah seluruh data rekam medik foto thoraks pada pasien dengan diagnosis radiologik efusi pleura. Hasil penelitian mendapatkan 77 sampel, terbanyak pada kelompok umur 45-59 tahun. Efusi pleura lebih banyak ditemukan pada laki-laki (65\%) dibandingkan perempuan (35\%). Berdasarkan lokasi efusi, 31 sampel dengan lokasi efusi pleura dekstra, 25 pasien dengan lokasi efusi pleura sinistra, dan 21 pasien dengan lokasi efusi pleura bilateral. Simpulan: Efusi pleura sering didapatkan pada pasien di atas 20 tahun. Pemeriksaan foto toraks merupakan salah satu pemeriksaan penunjang yang sering dilakukan untuk mendiagnosis efusi pleura.
\end{abstract}

Kata kunci: efusi pleura, foto toraks

Efusi pleura didefinisikan sebagai penimbunan cairan berlebihan dalam rongga pleura. Hal itu dapat disebabkan oleh peningkatan terbentuknya cairan pleura dalam interstisial paru, pleura parietalis atau rongga peritoneum atau oleh karena penurunan pembuangan cairan pleura oleh limfatik pleura parietalis. ${ }^{1}$

Menurut World Health Organization
(WHO), efusi pleura merupakan suatu gejala penyakit yang dapat mengancam jiwa. Secara geografis penyakit ini terdapat diseluruh dunia, bahkan menjadi problema utama di negara-negara yang sedang berkembang termasuk Indonesia. ${ }^{2}$

Estimasi kejadian efusi pleura di Amerika Serikat, dilaporkan sebanyak 1,3 juta kasus pertahun, dengan kasus efusi 
yang banyak disebabkan oleh gagal jantung kongestif, malignansi, dan emboli paru. Prevalensinya di dunia dilaporkan sebanyak 320 kasus per 100.000 orang di negara industri, dengan distribusi etiologi berhubungan dengan penyakitnya. Di Indonesia, tuberkulosis paru merupakan penyebab utama efusi pleura, disusul oleh keganasan. $^{3}$

Menurut Depkes RI, kasus efusi pleura mencapai 2,7\% dari penyakit infeksi saluran napas lainnya. Tingginya angka kejadian efusi pleura disebabkan keterlambatan penderita untuk memeriksakan kesehatan sejak dini. ${ }^{4}$

Pemeriksaan penunjang yang sering digunakan untuk pasien dengan efusi pleura, salah satunya ialah pemeriksaan foto toraks. Foto toraks atau sering disebut chest $x$-ray (CXR) adalah suatu proyeksi radiografi dari toraks untuk mendiagnosis kondisi-kondisi yang memengaruhi toraks, isi dan struktur didekatnya. Foto toraks menggunakan radiasi terionisasi dalam bentuk x-ray. Foto toraks digunakan untuk mendiagnosis banyak kondisi yang melibatkan dinding toraks, tulang toraks, dan struktur yang berada dalam kavitas toraks termasuk paru-paru, jantung dan saluran/pembuluh besar. ${ }^{5}$

Begitu banyak kasus efusi pleura di Indonesia, khususnya di Manado. Penelitian ini bertujuan untuk mendapatkan gambaran foto toraks pada pasien dengan efusi pleura di Bagian Radiologi FK Unsrat/SMF RSUP Prof. Dr. R. D. Kandou Manado periode November 2014-Oktober 2015.

\section{METODE PENELITIAN}

Penelitian ini merupakan penelitian deskriptif retrospektif. Lokasi penelitian berada di RSUP Prof. Dr. R. D. Kandou Manado. Populasi penelitian ialah semua data dari catatan medik pada formulir permintaan foto toraks, dan sampel semua data dari catatan medik pada formulir permintaan foto toraks dengan diagnosis radiologik efusi pleura. Alat dan bahan yang digunakan ialah hasil ekspertisi foto toraks dari penderita efusi pleura. Variabel penelitian yang di teliti yaitu: Jenis kelamin, umur, dan lokasi. Data yang terkumpul kemudian diolah dan disajikan dalam bentuk tabel.

\section{HASIL PENELITIAN}

Berdasarkan hasil penelitian retrospektif gambaran foto toraks pada efusi pleura di Bagian/SMF Radiologi FK Unsrat RSUP Prof. Dr. R. D Kandou Manado periode November 2014 - Oktober 2015, ditemukan 77 pasien dengan diagnosis radiologik efusi pleura.

Tabel 1 memperlihatkan 1 pasien (1\%) pada kelompok umur 15-19 tahun, 8 pasien (10\%) pada kelompok umur 20-29 tahun, 12 pasien (16\%) pada kelompok umur 3044 tahun, 28 orag pasien (36\%) pada kelompok umur 45-59 tahun, 22 pasien (29\%) pada kelompok umur 60-74 tahun, dan 6 pasien $(8 \%)$ pada kelompok umur $>75$ tahun.

Tabel 1. Distribusi sampel berdasarkan umur

\begin{tabular}{ccc}
\hline Umur & $\mathrm{n}$ & $\%$ \\
\hline 15-19 tahun & 1 & 1 \\
20-29 tahun & 8 & 10 \\
30-44 tahun & 12 & 16 \\
45-59 tahun & 28 & 36 \\
60-74 tahun & 22 & 29 \\
$>75$ tahun & 6 & 8 \\
Total & 77 & 100 \\
\hline
\end{tabular}

Tabel 2 berdasarkan jenis kelamin, didapatkan 50 orang laki-laki (65\%) dan 27 orang perempuan (35\%).

Tabel 2. Distribusi sampel berdasarkan jenis kelamin.

\begin{tabular}{ccc}
\hline Jenis kelamin & $\mathrm{n}$ & $\%$ \\
\hline Laki - laki & 50 & 65 \\
Perempuan & 27 & 35 \\
Total & 77 & 100 \\
\hline
\end{tabular}

Tabel 3 didapatkan bahwa 31 pasien (40\%) dengan lokasi efusi pleura dekstra, 25 pasien (33\%) dengan lokasi efusi pleura sinistra, dan 21 pasien (27\%) dengan lokasi efusi pleura bilateral. 
Tabel 3. Distribusi sampel berdasarkan lokasi

\begin{tabular}{ccc}
\hline Lokasi & N & $\%$ \\
\hline Dekstra & 31 & 40 \\
Sinistra & 25 & 33 \\
Bilateral & 21 & 27 \\
Total & 77 & 100 \\
\hline
\end{tabular}

\section{BAHASAN}

Berdasarkan kelompok umur (Tabel 1) didapatkan yang terbanyak yaitu 28 pasien (36\%) pada kelompok umur 45-59 tahun, diikuti 22 pasien (29\%) pada kelompok umur 60-74 tahun.

Pada Tabel 2 ditemukan bahwa penderita laki-laki berjumlah 50 orang (65\%) dan lebih banyak dibandingkan penderita perempuan yang berjumlah 27 orang (35\%). Hal ini biasanya dipengaruhi oleh faktor predisposisi yaitu laki-laki lebih sering merokok dan bekerja di luar rumah dibandingkan perempuan. ${ }^{6}$

Berdasarkan lokasi efusi pleura, pada Tabel 3 ditemukan bahwa terbanyak 31 pasien (40\%) dengan lokasi efusi pleura dextra.

\section{SIMPULAN}

Berdasarkan gambaran foto toraks pasien dengan diagnosis radiologik efusi pleura di Bagian/SMF Radiologi RSUP Prof Dr. R. D Kandou periode November 2014 - Oktober 2015, dapat disimpulkan bahwa hasil pemeriksaan foto toraks dengan diagnosis radiologik efusi pleura, didapatkan terbanyak pada umur 45-59 tahun, laki-laki lebih sering daripada perempuan, dengan lokasi efusi pleura terbanyak di bagian dekstra dibanding sinsitra dan bilateral.

\section{SARAN}

1. Perlu dilakukan pembenahan dalam kelengkapan data pasien untuk menjadi bahan penelitian selanjutnya.

2. Perlu dilakukan penyuluhan pengobatan yang adekuat pada penyakit-penyakit dasar yang dapat menimbulkan efusi pleura.

\section{DAFTAR PUSTAKA}

1. Fauci AS, Kasper DL, Longo DL, Loscalzo J, Braunwald E, Hauser SL, Jameson JL. Penyakit pleura dan mediastinum. Kosasih A, Widowati H, Saputra L, editors. Harrison Manual Kedokteran (2nd ed). Jakarta: Karisma Publishing Group, 2009; p. 147-51.

2. World Health Organization. Epidemiology and etiology of plural effusion, 2008

3. Rubins J. Pleural effusion. 5 september 2014. (cited 2 Oktober 2015. Available from: http://emedicine.medscape.com/articl e/299959-overview.

4. Departemen Kesehatan Republik Indonesia. 2006

5. Risnawati D. Gambaran hasil foto toraks pada pasien baru di Bagian/SMF Radiologi FK Unsrat BLU RSUP Prof. Dr. R. D. Kandou Manado periode Juni-Oktober 2014. Jurnal eBM 2015;1.

6. Khairani R, Syahruddin E, Partakusuma LG. Karakteristik efusi pleura di Rumah Sakit Persahabatan. J Respir Indo. 2012;32:155-9. 